\title{
Effects of legume seeds and processing treatment on growth, carcass traits and blood constituents of fattening lambs
}

\author{
A. Lestingi ${ }^{1 \#}$, M.A. Colonna ${ }^{2}$, G. Marsico ${ }^{2}$, S. Tarricone $^{2}$ \& A.M. Facciolongo ${ }^{3}$ \\ ${ }^{1}$ Department of Veterinary Medicine, University of Bari Aldo Moro, Strada provinciale Casamassima, Km 3, 70010, \\ Valenzano (BA), Italy \\ ${ }^{2}$ Department of Agricultural and Environmental Science, University of Bari Aldo Moro, Via G. Amendola 165/A, 70126, \\ Bari, Italy \\ ${ }^{3}$ Institute of Biosciences and BioResources, National Research Council, Via G. Amendola 165/A, 70126, Bari, Italy
}

(Received 1 July 2019; Accepted 21 August 2019; First published online 1 October 2019)

Copyright resides with the authors in terms of the Creative Commons Attribution 4.0 South African Licence.
See: http://creativecommons.org/licenses/by/4.0/za
Condition of use: The user may copy, distribute, transmit and adapt the work, but must recognise the authors and the South African
Journal of Animal Science.

\begin{abstract}
This study aimed to evaluate the effects of faba bean, white lupin and pea seed when fed as protein supplements on growth performance, carcass characteristics and haematological characteristics of growing lambs. Forty-eight Gentile di Puglia male lambs, weaned at $38 \pm 2$ days old with an average initial bodyweight of $12.8 \pm 0.5 \mathrm{~kg}$, were divided into six homogenous groups. The six dietary treatments were RFB (diet containing raw faba bean seeds); EFB (diet containing extruded faba bean seeds); RL (diet containing raw lupin seeds); EL (diet containing extruded lupin seeds); RP (diet containing raw pea seeds); and EP (diet containing extruded pea seeds). Feeding lupin seeds reduced average daily feed intake compared with the other protein sources. Carcass conformation, loin weight as a percentage of half-carcass weight, and fat weight as a percentage of loin weight improved in the lambs that consumed both EP and RP diets. Extrusion reduced hide weight as a percentage of empty bodyweight and fat weight as a percentage of leg weight. The protein source had a significant effect on glucose and total cholesterol concentrations, albumin, $\alpha_{1}$-globulin, $\beta$-globulin, and $\gamma$-globulin percentages and albumin-globulin ratios. The processing treatment decreased total cholesterol concentrations. Thus, feeding the various legumes did not affect growth performance, but only carcass characteristics; changes which may be due to the differences in feed intake. Extrusion also had minor effects, and further work is required to investigate the use of these protein sources, both raw and extruded.
\end{abstract}

Keywords: extrusion, faba bean, haematology, lupin, pea, protein source, slaughter data

${ }^{\#}$ Corresponding author: antonia.lestingi@uniba.it

\section{Introduction}

Various species of home-grown grain legumes, such as pea, faba bean, and lupin, may represent strategically important alternatives to soybean. They are widely available in Mediterranean areas and increase the sustainability of crop-livestock systems by safeguarding soil fertility and reducing greenhouse gas emissions and use of nitrogen fertilizer (Bonanno et al., 2012; Calabrò et al., 2015). Recently, seed legumes have been regarded as alternatives to soybean as sources of protein in animal feeding owing to disputes about the use of genetically modified organisms (GMOs) (Calabrò et al., 2015). In addition, legume grains have attracted attention as alternative vegetable protein components for feedstuffs that are used in organic production of meat (Bonanno et al., 2012).

The use of a diet based largely on faba bean for fattening lambs resulted in growth and meat characteristics similar to the most frequently used diets containing soybean meal as the main source of protein (Caballero et al., 1992; Lanza et al., 1999; Lanza et al., 2011). Replacement of soybean meal with pea in lamb diets did not significantly affect growth and slaughter traits (Lanza et al., 2003, 2011; Scerra et al., 2011). However, some studies reported reduced animal performance with the use of lupin owing to the high rumen degradability of its protein, but the issue has been controversial (Kung et al.,1991; Murphy \& McNiven, 1994; Stanford et al., 1996; Vicenti et al., 2009). In the authors' earlier studies, the use of diets that 
incorporated faba bean, lupin and pea, alone and in mixtures, as alternative protein sources to soybean in feeding for finishing lambs did not negatively affect the in vivo performances or the carcass yield and quality (Lestingi et al., 2015a, 2015b, 2016; Facciolongo et al., 2014, 2015). However, the authors continued with this research topic to determine the optimum percentages of these protein sources to include in feeds. Further, legumes such as peas, lupins, and faba beans require technological processing to reduce their nitrogen $(\mathrm{N})$ degradability if they are to be used as the main protein source in highly productive diets for ruminants (INRA, 1988; Masoero et al., 2005; Zagorakis et al., 2015).

Modern nutrition science suggests an optimum 60 to 40 (ratio of rumen degradable protein to rumen undegradable protein (RDP : RUP) for production of ruminant livestock. With an effective protein degradability above 0.6 , it is hard to sustain high total tract $\mathrm{N}$ digestibility (Milis \& Liamadis, 2008; Zagorakis et al., 2015). Moreover, $\mathrm{N}$ degradability plays the major role in the amount of energy that is wasted in transforming blood ammonia $\left(\mathrm{NH}_{3}\right)$ into urea and environmental pollution with $\mathrm{NH}_{3}$, both from urine and faeces (Miller \& Baig, 2002). The high protein degradability of legume grains in the rumen has led to investigations into means to protect against fermentation and thus increase the undegraded dietary protein component that escapes the rumen. Attempts to increase the utilization of legumes have employed a wide range of processing techniques, such as soaking, boiling, autoclaving, radiating, cooking, roasting, dehulling, germinating, fermenting, supplementing with various chemicals and enzymes and utilizing extrusion cooking (Bishnoi \& Khetarpaul, 1994; Alonso et al., 1998; Alonso et al., 2000).

The application of extrusion cooking to legume processing has developed quickly and can be regarded as a technology in its own right. Extrusion cooking has certain advantages, including versatility, high productivity, low operating costs, energy efficiency, and shorter cooking times. The temperatures reached by the feed during extrusion can be high $\left(200{ }^{\circ} \mathrm{C}\right)$, but the residence time at this elevated temperature is short ( 5 to 10 seconds). This tends to maximize the beneficial effects (preservation of nutrients) of heating feeds, while minimizing the detrimental effects (destruction of nutrients) (Serrano, 1997).

The effect of extrusion of pea, lupin and faba bean seed in sheep and cows has been considered in several studies. Extrusion of these alternative legume grains is effective in reducing their crude protein degradation in the rumen and in increasing the supply of dietary protein to the small intestine (Benchaar et al., 1994; Aufrère et al., 2001; Masoero et al., 2005). However, there has been limited research on the effect of extrusion cooking on growth performance and carcass characteristic of fattening lambs.

Moreover, apart from the authors' previous studies (Lestingi et al., 2015b, 2016; Facciolongo et al., 2014), they are not aware of reports on the effect of the use of faba bean, white lupin, and pea seeds, raw or after an extrusion treatment, on lamb blood parameters, some of which are important indicators of the animal's nutritional state and may be useful in identifying metabolic imbalances or disorders. Therefore, the objective of this study was to evaluate the effects of faba bean, white lupin and pea seed, and their processing treatment, raw or extruded, on growth, carcass characteristics and blood parameters of growing lambs.

\section{Material and Methods}

All procedures involving animals were conducted according to the Italian government guidelines (Directive 91/629/EEC, received in Italy by D.L. 533/92 and modified by D.L. 331/98).

The study was conducted on a farm in southern Italy (latitude: $41^{\circ} 5^{\prime} 54^{\prime \prime} 24 \mathrm{~N}$; longitude:16²46'43"68 E) at $620 \mathrm{~m}$ above sea level, during 7 weeks from November 2012 to January 2013. Forty-eight Gentile di Puglia male lambs, weaned at $38 \pm 2$ days old with an average initial bodyweight (BW) of $12.8 \pm 0.5 \mathrm{~kg}$ (mean \pm standard error) were divided into six homogenous groups for BW and age. They were housed in individual pens ( $1 \mathrm{~m}^{2}$ per head) with continuous access to water. The temperature in the pens ranged from 7 ${ }^{\circ} \mathrm{C}$ to $15{ }^{\circ} \mathrm{C}$. Lambs were assigned to one of six dietary treatments: RFB (diet containing raw faba bean seeds); EFB (diet containing extruded faba bean seeds); RL diet containing raw lupin seeds); EL (diet containing extruded lupin seeds); RP (diet containing raw pea seeds); and EP (diet containing extruded pea seeds). Local commercial pea (Pisum sativum L.), faba bean (Vicia faba L. var. minor) and lupin (Lupinus albus L.) seed were included in the diets at a rate of $250 \mathrm{~g} / \mathrm{kg}$ diet (on as fed basis). The chemical compositions, including the by-pass crude protein (CP) of the tested seeds, raw and extruded, are reported in Table1. Pea, faba bean and lupin seed were exposed to extrusion using the same industrial equipment used by Masoero et al. (2005), namely Anderson single-screw wet extruder with 300-350 Kg/h capacity and 120 A power absorption at Cortal Extrasoy (Vicenza, Italy). All pelleted total mixed rations (Table 2) were formulated to be isocaloric and isonitrogenous, and to meet the nutritional requirements of lambs (INRA, 1988).

Lambs were adapted to the ration for 10 days. Feed was offered daily at $08 \mathrm{~h} 00$ at a rate of $110 \%$ of ad libitum intake, which was calculated by weighing back refusals weekly. Feed samples were taken weekly and 
stored at $-20{ }^{\circ} \mathrm{C}$ until analysis. Straw was offered as a source of roughage. Straw intake was very low and was not recorded. Individual BW and feed intake were recorded weekly to calculate average daily gain (ADG), average daily feed intake (ADFI) and feed conversion ratio (FCR).

Table 1 Chemical compositions of legume seeds (dry matter basis)

\begin{tabular}{lcccccc}
\hline & \multicolumn{3}{c}{ Diets } \\
\cline { 2 - 7 } & \multicolumn{2}{c}{ Faba bean } & \multicolumn{2}{c}{ Lupin } & Pea \\
\cline { 2 - 7 } & Raw & Extruded & Raw & Extruded & Raw & Extruded \\
\cline { 2 - 7 } Dry matter, \% & 88.29 & 87.24 & 90.12 & 90.23 & 88.11 & 89.15 \\
Crude protein (CP), \% & 29.33 & 29.18 & 38.47 & 38.85 & 24.15 & 24.00 \\
Ether extract, \% & 1.78 & 1.98 & 8.39 & 10.84 & 1.38 & 1.77 \\
Ash, \% & 3.73 & 3.76 & 4.15 & 4.05 & 3.65 & 5.45 \\
Neutral detergent fibre, \% & 31.28 & 22.93 & 20.13 & 20.95 & 18.45 & 15.51 \\
Acid detergent fibre, \% & 12.86 & 14.68 & 12.87 & 13.18 & 9.87 & 7.09 \\
Starch, \% & 37.03 & 38.19 & 12.48 & 8.89 & 49.58 & 47.15 \\
CP enzymatic degradation (\%) & 81.67 & 51.05 & 95.01 & 91.06 & 87.20 & 74.95 \\
Bypass CP (g/kg dry matter) & 53.76 & 142.83 & 19.19 & 34.73 & 30.91 & 60.12 \\
\hline
\end{tabular}

Samples of each legume seed and the pelleted total mixed rations were ground in a hammer mill with a 1-mm screen and analysed using these AOAC procedures (2004): dry matter (DM) (method 934.01), ether extract (EE) (method 920.39), ash (method 942.05), CP (method 954.01), crude fibre (CF) (method 945.18), acid detergent fibre (ADF) (method 973.18), and amylase-treated neutral detergent fibre (aNDF) (method 2002.04). Starch was determined according to AOAC procedure 996.11. Protein degradability was assessed in vitro as suggested by Krishnammoorty et al. (1983). The protein values PDIE (protein digested in the small intestine allowed by the energy), and PDIN )protein digested in the small intestine allowed by the nitrogen) was estimated using the equations proposed by INRA (1988).

At the end of the trial, blood was drawn from the jugular vein of each animal into a Vacutainer ${ }^{\circledR}$ (Becton Dickinson, Mississauga, ON, L5N 0B3, Canada). The blood samples were analysed to determine the energy (glucose, total cholesterol, triglycerides) and protein (creatinine, urea, total protein and respective electrophoresis fractions). After the blood samples were collected, and within 30 minutes of having been collected, the blood samples were centrifuged at $1600 \times \mathrm{g}$ for 15 minutes. The serum was divided into aliquots, transported at $4{ }^{\circ} \mathrm{C}$ to the laboratory, and frozen at $-20^{\circ} \mathrm{C}$ until analyses were performed. Serum concentration of parameters was assessed using Assel reagents and a SEAC photometer with interferential filters. Serum protein electrophoresis was performed on agarose gel according to the Helena BioSciences technique (Helena Biosciences, Gateshead, United Kingdom

At $97 \pm 2$ days old, after fasting for 12 hours, but with free access to water and with slaughter weight having been recorded, all lambs were slaughtered by exsanguination according to veterinary police rules (D.P.R. 320/54). After slaughter, the hot carcass, hide, head, pluck and full and empty gastro-intestinal tract (GIT) were weighed. Carcasses were then hung by the Achilles tendon, chilled at $4{ }^{\circ} \mathrm{C}(80-82 \%$ relative humidity) for 24 hours and reweighed. After chilling, carcasses were evaluated for conformation, using a 115 point scale ( 1 = poor, $15=$ excellent) according to Colomer-Rocher et al. (1988), and fatness according to the EU scale (EEC Regulation 1278/94, 1994) for light lamb carcasses, which has 12 categories (1 = very scarce, 12 = important).

The weight of digestive content (full-empty GIT) was used to calculate the net dressing percentage (carcass weight after chilling/empty BW). The cold carcasses were then divided into two symmetrical sides. The right side was separated into cuts (neck, steak, brisket, shoulder, abdominal region, loin, leg) according to ASPA methods (1996). Loins and legs were dissected into tissue components (lean, separable fat and bone).

Statistical analysis was performed using the GLM procedure of SAS (SAS Institute Inc, Cary, NC, USA) with the linear model including protein sources $(P)$ and seed treatment $(T)$ effects, $P \times T$ interaction 
and experimental error. Least squares means (LSMEANS) were compared using the probability of difference option (PDIFF) in the LSMEANS statement of SAS. Significance was declared at $P<0.05$, while trends in the differences among means were declared at $P<0.10$.

Table 2 Ingredient and chemical composition the diets containing raw and extruded faba beans, lupin seeds and peas.

\begin{tabular}{|c|c|c|c|c|c|c|}
\hline & \multicolumn{6}{|c|}{ Diets } \\
\hline & \multicolumn{2}{|c|}{ Faba bean } & \multicolumn{2}{|c|}{ Lupin } & \multicolumn{2}{|c|}{ Pea } \\
\hline & Raw & Extruded & Raw & Extruded & Raw & Extruded \\
\hline \multicolumn{7}{|c|}{ Ingredient composition, \% (as-fed basis) } \\
\hline Corn & 12.0 & 12.0 & 18.0 & 18.0 & 10.0 & 10.0 \\
\hline Oat & 15.0 & 15.0 & 12.0 & 12.0 & 8.0 & 8.0 \\
\hline Barley & 5.0 & 5.0 & 26.0 & 26.0 & - & - \\
\hline Dehydrated alfalfa 12 & 17.0 & 17.0 & 5.0 & 5.0 & 22.5 & 22.5 \\
\hline Straw & 4.0 & 4.0 & 8.5 & 8.5 & 3.0 & 3.0 \\
\hline Molasses & 1.7 & 1.7 & 1.7 & 1.7 & 1.7 & 1.7 \\
\hline Faba bean meal & 25.0 & - & - & - & - & - \\
\hline Extruded faba bean & - & 25.0 & - & - & - & - \\
\hline Lupin meal & - & - & 25.0 & - & - & - \\
\hline Extruded lupin & - & - & - & 25.0 & - & - \\
\hline Pea meal & - & - & - & - & 25.0 & - \\
\hline Extruded pea & - & - & - & - & - & 25.0 \\
\hline Wheat bran & 15.5 & 15.5 & - & - & 25.0 & 25.0 \\
\hline Soy bean oil & 1.0 & 1.0 & - & - & 1.0 & 1.0 \\
\hline Calcium carbonate & 1.8 & 1.8 & 1.8 & 1.8 & 1.8 & 1.8 \\
\hline Dicalcium phosphate & 1.0 & 1.0 & 1.0 & 1.0 & 1.0 & 1.0 \\
\hline Sodium chloride & 0.5 & 0.5 & 0.5 & 0.5 & 0.5 & 0.5 \\
\hline Vitamin mineral premix & 0.5 & 0.5 & 0.5 & 0.5 & 0.5 & 0.5 \\
\hline \multicolumn{7}{|c|}{ Chemical composition (dry matter basis) } \\
\hline Moisture, \% (as fed) & 13.4 & 13.7 & 13.1 & 13.7 & 13.8 & 13.5 \\
\hline Crude protein, $\%$ & 17.1 & 16.6 & 17.2 & 17.4 & 16.3 & 16.8 \\
\hline Ether extract, \% & 4.3 & 4.0 & 4.4 & 4.3 & 4.2 & 4.8 \\
\hline Crude fibre, $\%$ & 11.8 & 14.7 & 13.7 & 14.2 & 13.4 & 11.9 \\
\hline Ash, \% & 3.8 & 3.8 & 4.1 & 4.1 & 3.7 & 4.5 \\
\hline Neutral detergent fibre, $\%$ & 30.4 & 29.0 & 25.5 & 19.8 & 31.2 & 29.6 \\
\hline Acid detergent fibre, $\%$ & 15.4 & 19.2 & 13.3 & 13.9 & 15.5 & 14.7 \\
\hline Starch, \% & 26.4 & 26.6 & 35.2 & 36.3 & 27.8 & 27.3 \\
\hline $\mathrm{PDIN}^{1}$ (g/kg dry matter) & 105.0 & 110.5 & 113.5 & 115.6 & 97.6 & 99.9 \\
\hline $\mathrm{PDIE}^{2}$ (g/kg dry matter) & 93.5 & 110.4 & 88.5 & 90.7 & 90.2 & 95.3 \\
\hline Metabolizable energy (MJ/kg) & 11.1 & 10.9 & 10.8 & 10.8 & 11.1 & 11.1 \\
\hline
\end{tabular}

${ }^{1}$ PDIN: protein digested in the small intestine allowed by the nitrogen

${ }^{2} \mathrm{PDIE}$ : protein digested in the small intestine allowed by the energy

\section{Results and Discussion}

Feeding lupin seed significantly $(P<0.01)$ reduced mean daily feed intake in relation to the other protein sources (Table 3$)$. Lambs that were fed peas had greater $(P<0.05)$ ADFI than lambs fed faba beans. These results are consistent with the authors' previous studies (Lestingi et al., 2015b; Lestingi et al., 2016). 
As discussed in these works, some lupin components, in particular the alkaloids, may have exerted a negative effect on the ADFI, although the authors did not measure these components. The variety of sweet lupin that was used in the present study was Multitalia, an old Italian sweet variety, which is has not been selected for reduced alkaloid content to any great extent (Calabrò et al., 2015). This may have influenced palatability of the lupin seeds by giving them a bitter taste. The lambs that consumed lupin seed also tended $(P<0.10)$ to have reduced ADG compared with lambs that were fed the other protein sources (Table 3$)$.

Although the lambs that were fed the various protein sources had comparable EUROP classification scores for carcass fatness, pea and faba bean-fed lambs had on average 2.07 units higher $(P<0.01)$ scores for conformation than lambs that received the lupin seed (Table 3). The minimal difference in carcass fat score among dietary groups could be attributed to the unique pattern of development of carcass fat depots. Lambs deposit most of the fat around the viscera and less of it in the carcass (Carrasco et al., 2009). On the other hand, the increased levels of carcass conformation with faba bean and pea allowances suggest that lambs responded to nutritional treatment by building up more muscle (Sheridan et al., 2003). The reduced feed intake in lupin-fed lambs probably decreased the availability of energy for deposition of muscle tissue, resulting in the subsequent reduction of carcass conformation. Slaughter BWs of lambs that consumed lupin seed were numerically lower than in lambs that received the other protein sources, although this effect was not significant.

Table 3 Effects of protein source and extrusion treatment on in vivo performances and slaughtering data (\% of empty bodyweight) of fattening lambs

\begin{tabular}{|c|c|c|c|c|c|c|c|c|c|}
\hline & \multicolumn{3}{|c|}{ Protein source $(P)$} & \multicolumn{2}{|c|}{ Treatment $(T)$} & \multirow[b]{2}{*}{$\mathrm{MSE}^{1}$} & \multicolumn{3}{|c|}{$P$-value } \\
\hline & Faba bean & Lupin & Pea & Raw & Extruded & & $P$ & $\mathrm{~T}$ & $P \times T$ \\
\hline Initial bodyweight (kg) & 12.51 & 12.04 & 12.25 & 12.21 & 12.32 & 1.661 & 0.723 & 0.830 & 0.782 \\
\hline Slaughter bodyweight (kg) & 21.49 & 20.33 & 20.67 & 20.97 & 20.69 & 2.115 & 0.292 & 0.657 & 0.809 \\
\hline Average daily gain $(\mathrm{kg} / \mathrm{d})$ & 0.194 & 0.166 & 0.188 & 0.185 & 0.180 & 0.036 & 0.077 & 0.575 & 0.502 \\
\hline Average daily feed intake $(\mathrm{kg} / \mathrm{d})$ & $0.74^{\mathrm{Ab}}$ & $0.69^{\mathrm{B}}$ & $0.77^{\mathrm{Aa}}$ & 0.72 & 0.74 & 0.041 & 0.001 & 0.150 & 0.080 \\
\hline Feed conversion ratio $(\mathrm{kg} / \mathrm{kg})$ & 3.91 & 4.41 & 4.21 & 4.13 & 4.23 & 1.028 & 0.428 & 0.738 & 0.446 \\
\hline Empty BW (kg) & 19.31 & 17.93 & 18.30 & 18.71 & 18.32 & 1.898 & 0.114 & 0.484 & 0.917 \\
\hline Carcass conformation & $12.0^{\mathrm{A}}$ & $9.94^{\mathrm{B}}$ & $12.03^{\mathrm{A}}$ & 11.77 & 10.87 & 2.215 & 0.008 & 0.110 & 0.972 \\
\hline Carcass fat score & 6.75 & 6.56 & 6.87 & 6.96 & 6.50 & 1.338 & 0.713 & 0.140 & 0.626 \\
\hline Hide & 13.92 & 14.13 & 14.14 & $13.56^{\mathrm{b}}$ & $14.57^{\mathrm{a}}$ & 1.521 & 0.902 & 0.026 & 0.266 \\
\hline Empty digestive tract & 8.36 & 8.41 & 8.29 & 8.21 & 8.49 & 1.095 & 0.952 & 0.379 & 0.626 \\
\hline Omentun & 0.80 & 0.69 & 0.80 & 0.84 & 0.68 & 0.401 & 0.668 & 0.184 & 0.478 \\
\hline Chilling loss & 1.77 & 2.01 & 1.58 & 1.63 & 1.94 & 1.881 & 0.808 & 0.569 & 0.273 \\
\hline Head & 4.61 & 4.72 & 4.95 & 4.81 & 4.72 & 0.480 & 0.134 & 0.533 & 0.885 \\
\hline Pluck & 5.32 & 5.34 & 5.43 & 5.41 & 5.32 & 0.302 & 0.574 & 0.337 & 0.445 \\
\hline Net cold dressing percentage & 48.80 & 51.43 & 49.52 & 50.43 & 49.40 & 3.906 & 0.156 & 0.364 & 0.449 \\
\hline
\end{tabular}

${ }^{1}$ Mean square error

A, $B$ row least squares means with different superscripts differ significantly at $P<0.01$

a, b row least squares means with different superscripts differ significantly at $P<0.05$

The percentage of hide on the empty bodyweight was the only slaughtering parameter that was affected $(P<0.05)$ by processing treatment $($ Table 3$)$. Lambs fed raw unprocessed seed showed lower percentages of hide compared with lambs fed extruded seeds. The hide included the wool and it could be speculated that the supply of intestinal amino acids, particularly the sulphur-containing amino acids (SAA), was improved by the extrusion process. Wool growth is a function mainly of the amount of amino acids that reach the intestine rather than energy supply (Rodehutscord et al., 1999). Furthermore, the amino acid pattern of the protein that reaches the intestine may affect wool growth, since SAA are first limiting in terms of wool protein synthesis (Rodehutscord et al., 1999). It has been reported that the ruminally degradable proportion of dietary protein becomes a critical factor for wool growth and, on isonitrogenous diets, wool 
growth responds well to less degradable proteins, particularly when they are high in SAA concentration (Rodehutscord et al., 1999).

Section data are reported in Table 4. Protein sources influenced $(P<0.01)$ the percentages of loins on the half-carcass weight, which were higher $(P<0.01)$ in lambs that consumed pea seed than in lambs that received the remaining protein sources. As discussed, the results could be ascribed to differences in feed intake.

No significant differences were found between groups for the other section parameters.

Table 4 Effects of protein source and extrusion treatment on section data (\% of half carcass weight) of fattening lambs

\begin{tabular}{|c|c|c|c|c|c|c|c|c|c|}
\hline & \multicolumn{3}{|c|}{ Protein source $(P)$} & \multicolumn{2}{|c|}{ Treatment $(\mathrm{T})$} & \multirow[b]{2}{*}{$\mathrm{MSE}^{1}$} & \multicolumn{3}{|c|}{$P$-value } \\
\hline & Faba bean & Lupin & Pea & Raw & Extruded & & $P$ & $\mathrm{~T}$ & $\mathrm{P} \times \mathrm{T}$ \\
\hline Half carcass weight $(\mathrm{kg})$ & 4.45 & 4.36 & 4.31 & 4.43 & 4.31 & 0.612 & 0.813 & 0.492 & 0.755 \\
\hline \multicolumn{10}{|c|}{ Half carcass composition (\%) } \\
\hline Neck & 9.56 & 9.16 & 9.12 & 9.41 & 9.15 & 0.676 & 0.137 & 0.199 & 0.119 \\
\hline Steaks & 15.22 & 14.88 & 14.47 & 14.68 & 15.03 & 0.998 & 0.115 & 0.221 & 0.269 \\
\hline Brisket & 11.58 & 11.41 & 11.22 & 11.24 & 11.57 & 0.734 & 0.390 & 0.128 & 0.738 \\
\hline Shoulder & 16.81 & 17.11 & 16.59 & 16.95 & 16.72 & 0.683 & 0.110 & 0.268 & 0.394 \\
\hline Loin & $8.27^{\mathrm{B}}$ & $8.35^{\mathrm{B}}$ & $8.94^{\mathrm{A}}$ & 8.61 & 8.44 & 0.603 & 0.006 & 0.339 & 0.064 \\
\hline Abdominal region & 4.86 & 4.91 & 5.03 & 4.94 & 4.92 & 0.506 & 0.616 & 0.901 & 0.287 \\
\hline Leg & 31.79 & 32.18 & 32.32 & 32.03 & 32.17 & 0.838 & 0.193 & 0.570 & 0.663 \\
\hline Kidney fat & 0.72 & 0.87 & 0.97 & 0.89 & 0.82 & 0.302 & 0.063 & 0.475 & 0.370 \\
\hline Kidney & 0.80 & 0.77 & 0.86 & 0.83 & 0.79 & 0.148 & 0.251 & 0.314 & 0.264 \\
\hline Testicle & 0.38 & 0.36 & 0.46 & 0.43 & 0.37 & 0.133 & 0.079 & 0.150 & 0.159 \\
\hline
\end{tabular}

${ }^{1}$ Mean square error
${ }_{A}, B$
row least squares means with different superscripts differ significantly at $P<0.01$

Data on the dissection of legs and loins are shown in Table 5. Seed treatment affected $(P<0.05)$ leg fat percentages and lean-to-fat ratios. It is well known that a number of components in legumes may exert a negative effect on the nutritional quality of their proteins. Protease inhibitors and lectins are among these components (Masoero et al., 2005). Protease inhibitors exert their antinutritional effect by reducing or preventing the digestion of nutrients and possibly impairing body metabolism, growth and health (Grant, 1999). Owing to their ability to bind to carbohydrate receptors of gut epithelial cells, lectins not only interfere with nutrient absorption but may also be taken up systemically and affect hormone balance and lipid and muscle metabolism (Grant, 1999). It could be speculated that the effect of extrusion on leg fat percentages was related to the inactivation of these antinutritional factors. Consistently with this speculation, Alonso et al. (2002) hypothesized reduced body lipid deposition in rats by feeding extruded pea diets.

Protein sources affected the percentages of lean $(P<0.01)$ and fat $(P<0.01)$ ratios, as well as lean to fat ratios $(P<0.01)$ in loins. Lean percentages were lower in loins from pea-fed lambs than in loins from lupin-fed $(P<0.01)$ or faba bean-fed $(P<0.05)$ lambs. On the contrary, fat percentages were higher in loins from pea-fed lambs in comparison with loins from lupin-fed $(P<0.01)$ or faba bean-fed $(P<0.05)$ lambs. Consequently, lambs fed pea seeds had loins with lower lean-to-fat ratios than lambs fed lupin $(P<0.01)$ or faba bean $(P<0.05)$ seeds. These results could be related to the differences in ADFI, because the amount of carcass fat depots has been positively related to energy intake (Chestnutt, 1994; Carrasco et al., 2009).

The effects of protein source and processing treatment on blood constituents are presented in Table 6. The concentrations of the plasma metabolites in all the experimental animals were within the typical ranges reported for sheep (Abdel-Ghani et al., 2011; Lestingi et al., 2015b; Lestingi et al., 2016). 
Table 5 Effects of protein source and extrusion treatment on composition of lamb leg and loin

\begin{tabular}{|c|c|c|c|c|c|c|c|c|c|}
\hline & \multicolumn{3}{|c|}{ Protein source $(P)$} & \multicolumn{2}{|c|}{ Treatment $(T)$} & \multirow[b]{2}{*}{$\mathrm{MSE}^{1}$} & \multicolumn{3}{|c|}{$P$-value } \\
\hline & Faba bean & Lupin & Pea & Raw & Extruded & & $P$ & $\mathrm{~T}$ & $\mathrm{P} \times \mathrm{T}$ \\
\hline Leg weight (kg) & 1.43 & 1.43 & 1.40 & 1.41 & 1.42 & 0.207 & 0.872 & 0.890 & 0.480 \\
\hline Lean (\% leg weight) & 62.83 & 64.46 & 63.01 & 62.98 & 6.89 & 3.418 & 0.348 & 0.362 & 0.550 \\
\hline Fat (\% leg weight) & 10.88 & 10.70 & 11.54 & $11.67^{\mathrm{a}}$ & $10.41^{b}$ & 2.037 & 0.474 & 0.037 & 0.236 \\
\hline Bone (\% leg weight) & 26.28 & 24.84 & 25.44 & 25.34 & 25.70 & 3.021 & 0.411 & 0.684 & 0.074 \\
\hline Lean/bone & 2.46 & 2.64 & 2.45 & 2.50 & 2.56 & 0.384 & 0.375 & 0.605 & 0.183 \\
\hline Lean+fat/bone & 2.89 & 3.07 & 2.94 & 2.96 & 2.97 & 0.419 & 0.436 & 0.942 & 0.093 \\
\hline Lean/ fat & 5.97 & 6.32 & 5.69 & $5.55^{b}$ & $6.44^{\mathrm{a}}$ & 1.360 & 0.431 & 0.028 & 0.610 \\
\hline Loin weight (kg) & 0.37 & 0.37 & 0.39 & 0.39 & 0.37 & 0.060 & 0.503 & 0.273 & 0.551 \\
\hline Lean (\% loin weight) & $45.65^{\mathrm{a}}$ & $46.73^{\mathrm{A}}$ & $41.98^{\mathrm{Bb}}$ & 45.29 & 44.29 & 4.208 & 0.007 & 0.413 & 0.485 \\
\hline Fat (\% loin weight) & $23.19^{b}$ & $22.19^{B}$ & $25.99^{\mathrm{Aa}}$ & 23.55 & 24.03 & 3.949 & 0.006 & 0.680 & 0.967 \\
\hline Bone (\% loin weight) & 31.15 & 31.07 & 32.02 & 31.15 & 31.68 & 4.060 & 0.765 & 0.652 & 0.329 \\
\hline Lean/bone & 1.47 & 1.54 & 1.36 & 1.47 & 1.44 & 0.283 & 0.204 & 0.739 & 0.321 \\
\hline Lean+fat/bone & 2.22 & 2.27 & 2.20 & 2.24 & 2.23 & 0.425 & 0.887 & 0.932 & 0.364 \\
\hline Lean/ fat & $2.04^{\mathrm{a}}$ & $2.18^{\mathrm{A}}$ & $1.65^{\mathrm{Bb}}$ & 2.01 & 1.91 & 0.460 & 0.008 & 0.437 & 0.978 \\
\hline
\end{tabular}

\footnotetext{
${ }^{1}$ Mean square error

A, B row least squares means with different superscripts differ significantly at $P<0.01$

${ }^{a}$, b row least squares means with different superscripts differ significantly at $P<0.05$
}

Table 6 Effects of protein source and extrusion treatment on serum constituents of fattening lambs

\begin{tabular}{|c|c|c|c|c|c|c|c|c|c|}
\hline & \multicolumn{3}{|c|}{ Protein source $(P)$} & \multicolumn{2}{|c|}{ Treatment (T) } & \multirow[b]{2}{*}{$\mathrm{MSE}^{1}$} & \multicolumn{3}{|c|}{$P$-value } \\
\hline & Faba bean & Lupin & Pea & Raw & Extruded & & $\mathrm{P}$ & $\mathrm{T}$ & $\mathrm{P} \times \mathrm{T}$ \\
\hline Glucose (mg/dl) & $74.61^{b}$ & $86.80^{\mathrm{a}}$ & $79.58^{\mathrm{ab}}$ & 82.03 & 78.63 & 10.715 & 0.013 & 0.346 & 0.052 \\
\hline Total cholesterol (mg/dl) & $45.43^{B}$ & $46.59^{B}$ & $60.19^{A}$ & $57.54^{\mathrm{A}}$ & $43.93^{\mathrm{B}}$ & 11.843 & 0.001 & 0.001 & 0.067 \\
\hline Triglycerides (mg/dl) & 23.30 & 25.01 & 24.77 & 25.22 & 23.50 & 6.176 & 0.724 & 0.366 & 0.801 \\
\hline Urea (mg/dl) & 37.22 & 35.48 & 38.71 & 35.13 & 39.14 & 8.684 & 0.608 & 0.114 & 0.440 \\
\hline Creatinine (mg/dl) & 1.18 & 1.15 & 1.23 & 1.23 & 1.15 & 0.312 & 0.726 & 0.383 & 0.986 \\
\hline Total protein (g/dl) & 5.76 & 5.91 & 5.70 & 5.81 & 5.77 & 0.358 & 0.272 & 0.709 & 0.697 \\
\hline Albumin (\%) & $65.69^{A}$ & $63.03^{B}$ & $65.91^{A}$ & 64.79 & 64.97 & 1.737 & 0.001 & 0.748 & 0.393 \\
\hline$\alpha_{1}$-globulin (\%) & $6.34^{\mathrm{A}}$ & $7.21^{\mathrm{B}}$ & $6.21^{A}$ & 6.56 & 6.62 & 0.742 & 0.001 & 0.763 & 0.691 \\
\hline$\alpha_{2}$-globulin (\%) & 13.44 & 13.53 & 13.31 & 13.57 & 13.28 & 1.042 & 0.853 & 0.367 & 0.906 \\
\hline$\beta$-globulin (\%) & $3.83^{a}$ & $4.46^{b}$ & $4.43^{b}$ & 4.29 & 4.19 & 0.702 & 0.042 & 0.667 & 0.026 \\
\hline Y-globulin (\%) & $11.33^{\mathrm{a}}$ & $11.69^{\mathrm{A}}$ & $10.09^{\mathrm{Bb}}$ & 10.70 & 11.37 & 1.262 & 0.003 & 0.090 & 0.345 \\
\hline Albumin/Globulin & $1.88^{\mathrm{A}}$ & $1.71^{\mathrm{B}}$ & $1.94^{\mathrm{A}}$ & 1.84 & 1.84 & 0.123 & 0.001 & 0.889 & 0.126 \\
\hline
\end{tabular}

Lambs that were fed lupin seeds had a greater concentration of plasma glucose than lambs fed faba bean seeds $(P<0.05)$. Lambs that were fed peas were intermediate and not different from those fed either of the other seeds. The higher glucose concentrations in lambs fed lupin diets compared with those fed faba 
bean diets may be explained by the dietary inclusion rates of barley, which is rich in rapidly degradable starch in the rumen.

Feeding pea seed increased $(P<0.01)$ total cholesterol concentration relative to the other two legume seeds. Decreased levels of total cholesterol in the blood of lambs that were fed on diets containing faba bean and lupin seed were observed in a previous study (Facciolongo et al., 2014). These two protein sources have been shown to have beneficial effects in animals and humans by reducing total serum cholesterol (Macarulla et al., 2001; Viveros et al., 2007). Their hypocholesterolaemic effect is confirmed in the present study.

Processing legume seed by extrusion exerted a diminishing effect $(P<0.01)$ on plasma total cholesterol concentrations. This decrease may be related to some positive changes in rumen fermentation and population of microorganisms (bacteria and protozoa). The processing of legume seeds can also manipulate the sites of digestion of starch and of protein (Solanas et al., 2008). Extrusion disrupts the protein matrix surrounding starch granules, and results in the extensive gelatinization of the starch, rendering it more susceptible to enzymatic hydrolysis in the rumen (Offner et al., 2003). This consequently increases the energy that is available for microbial growth. Therefore, the extrusion in the conditions of this experiment may have resulted in starch gelatinization, thereby increasing its availability to enzymatic attack and consequently its fermentation in the rumen. Such a hypothesis is consistent with the results of Masoero et al. (2005) who observed increased starch digestibility in vitro of these extruded seeds (that is peas, faba beans, and lupins) compared with the untreated seeds. The higher degradability of starch in the rumen has been shown to change rumen fermentation patterns by increasing that production of short chain fatty acids, (particularly propionate), which has further been related to reduced synthesis of triglyceride and cholesterol in the liver cells, as well as to changes in the lipid profile of blood (Malekkhahi et al., 2015).

Lupin-fed lambs had reduced $(P<0.01)$ percentages of serum albumin compared with lambs that were fed the other two protein sources, while they showed the opposite effect on $\alpha_{1}$-globulin percentages $(P$ $<0.01)$. The significant effect of $P \times T$ interaction showed that extrusion increased the $\beta$-globulin content of faba beans, but reduced it for lupin seeds and peas (Table 7). Lambs that consumed raw faba bean seed had reduced $(P<0.05)$ serum $\beta$-globulin concentration compared with lambs that received the other raw legume seeds. However, serum $\beta$-globulin concentrations did not differ among the legume seeds when they were fed to the lambs after being extruded.

Table 7 Effect of interaction between protein source and extrusion treatment on $\beta$-globulin in blood of fattening lambs (least squares mean \pm standard error)

\begin{tabular}{|c|c|c|c|c|c|c|}
\hline & \multicolumn{2}{|c|}{ Faba bean } & \multicolumn{2}{|c|}{ Lupin } & \multicolumn{2}{|c|}{ Pea } \\
\hline & Raw & Extruded & Raw & Extruded & Raw & Extruded \\
\hline$\beta$-globulin, \% & $3.46^{a} \pm 0.26$ & $4.20^{b} \pm 0.29$ & $4.58^{c} \pm 0.26$ & $4.34^{b} \pm 0.26$ & $4.83^{c} \pm 0.26$ & $4.04^{b} \pm 0.26$ \\
\hline
\end{tabular}

${ }^{a, b, c}$ Least squares means with different superscripts differ significantly at $P<0.05$

Lambs that received the pea diet had reduced $\gamma$-globulin percentages compared with lambs that consumed the lupin $(P<0.01)$ or faba bean $(P<0.05)$ diets. The present results pertaining to serum protein fractions are in agreement with previous observations from lambs that received the same protein sources (Facciolongo et al., 2014). In particular, serum albumin levels were reduced by the addition of lupin seeds to the diet of chickens (Viveros et al., 2007). The higher $\alpha_{1}$-globulin percentages observed in lambs that received lupin seeds compared with lambs that were fed with the other protein sources may be related to a cholesterol-reducing effect of lupin seed. The protein sources used in the current study have nutraceutical properties that can affect serum cholesterol, as mentioned above, although they do not all have the same efficacy, as shown in studies on rats (Macarulla et al., 2001; Sirtori et al., 2004). The lipid-lowering mechanism of these legume grains seems to be carried out through various mechanisms including their effect on the serum levels of high-density, very low density and low density lipoproteins, which are known to migrate in the fractions $\alpha_{1}, \alpha_{2}$, and $\beta$ of serum protein electrophoresis, respectively (Kaneko, 1989). Similarly, it may be assumed that the lowest $\beta$-globulin percentages that were observed in lambs fed with raw faba bean rations, in comparison with the rations containing the other two raw seeds, could be associated with the cholesterol-lowering effect of faba bean seed. The lack of differences in lambs that were fed with extruded grain legumes might be associated with the cholesterol-lowering effect that is exerted by extrusion. The most 
significant $\gamma$-globulins are immunoglobulins (antibodies) and these are important protein for proper body functioning, specifically the immune system, being the antibodies that protect from the attack of pathogens. Recently, enzymatic protein hydrolysates of yellow pea seed have been shown to possess high antioxidant and antibacterial activities (Ndiaye et al., 2012). The relatively low $\gamma$-globulin percentages observed in peafed lambs support the speculation that pea proteins may have interfered with the immune system of the animals. Finally, $\mathrm{A} / \mathrm{G}$ ratios were lower $(P<0.01)$ in lambs from lupin group compared with lambs that were fed peas or faba beans. The $A / G$ ratios obtained for the lupin-fed lambs are related to the differences previously observed in the individual fractions.

\section{Conclusions}

The use of pea seeds in diets for fattening lambs increased their feed intake compared with diets that contained lupin or faba bean as protein sources. However, this increase in feed intake did not result in a significant improvement in their growth. Carcass conformation, the percentage of loin in the half carcass weight, and the percentages of lean and fat in the loin were the only parameters that were affected by protein sources, probably because of the changes in feed intake. Various blood parameters were influenced by protein sources. This would be indicative of the interference that the legume seeds may have in the metabolism of nutrients and in maintaining a good state of health. Extrusion of the oils from these seeds had few effects, resulting only in differences in hide weight as a percentage of empty BW, the percentage of fat in the leg, and blood cholesterol level. The results would lead the authors to speculate on a relationship between consumption of extruded grain legumes and lipid and protein metabolism. Further work is required to investigate the use of these protein sources and their post-harvest processing, especially in terms of more recently selected lupine varieties and their effects on meat quality.

\section{Acknowledgments}

All the authors of the manuscript acknowledge and thank their own universities and institutes.

\section{Authors' Contributions}

All the authors contributed from the onset of the study and approved of the final version.

\section{Conflict of Interest Declaration}

The authors have no conflict of interest to declare.

\section{References}

Abdel-Ghani, A.A., Solouma, G.M.A., AbdElmoty, A.K.I., Kassab, A.Y. \& Soliman, E.B., 2011. Productive performance and blood metabolites as affected by protected protein in sheep. Open J. Anim. Sci. 1, 24-32.

Alonso, R., Aguirre, A. \& Marzo, F., 2000. Effect of extrusion and traditional processing methods on antinutritents and in vitro digestibility of protein and starch in faba and kidney beans. Food Chem. 68, 159-165.

Alonso, R., Orue, E., \& Marzo, F., 1998. Effects of extrusion and conventional processing methods on protein and antinutritional factor contents in pea seeds. Food Chem. 63(4), 505-512.

Alonso, R., George Grant, G., Frühbeck, G. \& Marzo, F., 2002. Muscle and liver protein metabolism in rats fed raw or heat-treated pea seeds. J. Nutr. Biochem. 13, 611-618.

AOAC, 2004. Official Methods of Analysis, 18th ed. Association of Official Analytical Chemists, Arlington, VA, USA.

ASPA, 1996. Metodiche Per La Determinazione Delle Caratteristiche QualitativeDella Carne (Procedures for Meat Quality Evaluation). Scientific Association of Animal Production, Perugia, Italy.

Aufrère, J., Graviou, D., Melcion, J.P. \& Demarquilly C., 2001. Degradation in the rumen of lupin (Lupinus albus L.) and pea (Pisum sativum L.) seed proteins. Effect of heat treatment. Anim. Feed Sci. Technol. 92, 215-236.

Benchaar, C., Moncoulon, R., Bayourthe, C. \& Vernayl, M., 1994. Effects of a supply of raw or extruded white lupin seeds on protein digestion and amino acid absorption in dairy cows. J. Anim. Sci. 72, 492-501.

Bishnoi, S. \& Khetarpaul, N., 1994. Saponin content and trypsin inhibitor of pea cultivars: Effect of domestic processing and cooking methods. J. Food Sci. Technol. 31, 73-76.

Bonanno, A., Tornambè, G., Di Grigoli, A., Genna, V., Bellina, V., Di Miceli, G. \& Dario Giambalvo, D., 2012. Effect of legume grains as a source of dietary protein on the quality of organic lamb meat. J. Sci. Food Agric. 92, 28702875.

Caballero, R., Rioperez, J., Fernandez, E., Marin, M.T. \& Fernandez, C., 1992. A note on the use of field beans (Vicia faba) in lamb finishing diet. Anim. Prod. 54, 441-444.

Calabrò, S., Cutrignelli, M.I., Lo Presti, V., Tudisco, R., Chiofalo, V., Grossi, M., Infascelli, F. \& Chiofalo, B., 2015. Characterization and effect of year of harvest on the nutritional properties of three varieties of white lupine (Lupinusalbus L.). J. Sci. Food Agric. Doi: 10.1002/jsfa.7049.

Carrasco, S., Ripoll, G., Sanz, A., Álvarez-Rodríguez, J., Panea, B., Revilla, R. \& Joy, M., 2009. Effect of feeding system on growth and carcass characteristics of Churra Tensina light lambs. Livest. Sci. 121, 56-63.

Chestnutt, D.M.B., 1994. Effect of lamb growth rate and growth pattern on carcass fat levels. J. Anim. Prod. 58, 77-85.

Colomer-Rocher, F.R., Delfa, R. \& Sierra, I., 1988. Método normalizado para el estudio de los caracteres cuantitativos y cualitativos de las canales ovinas producidas en el area mediterránea, según los sistemas de producción [Method 
for the study of quantitative and qualitative characters of carcasses sheep produced in the mediterranean area, as production systems]. Edita Instituto Nacional de Investigación Agraria (INIA) Madrid Spain) no 17, pp. 19-41.

EEC Regulation, 1994. Council Regulation (EC) No May 1994 amending Regulation (EEC) No 338/91 determining the community standard quality of fresh or chilled sheep carcasses and Regulation (ECC) No 2137/92 concerning the community scale for the classification of carcasses of ovine animals and determining the community standard quality of fresh or chilled sheep carcasses. Off. J. L 140 03-06-1994.

Facciolongo, A.M., De Marzo, D., Ragni, M., Lestingi, A. \& Toteda, F., 2015. Use of alternative protein sources for finishing lambs. 2. Effects on chemical and physical characteristics and fatty acid composition of meat. Prog. Nutr. 17(2), 165-173.

Facciolongo, A.M., Rubino, G., Zarrilli, A., Vicenti, A., Ragni, M. \& Toteda, F., 2014. Alternative protein sources in lamb feeding 1 Effects on productive performances, carcass characteristics and energy and protein metabolism. Prog. Nutr. 16 (2), 105-115.

Grant, G., 1999. Plant lectins. In: Caygill, Mueller-Harvey (eds). Secondary plant products. Antinutritional and beneficial actions in animal feeding. pp. 87-110. Nottingham University Press, Nottingham, UK.

INRA, 1988. Alimentation des bovines, ovins et caprins. INRA, Paris, France.

Kaneko, JJ., 1989. Serum proteins and the dysproteinemias. In: Kaneko, J.J. (ed). Clinical biochemistry of domestic animals. Academic Press Inc, San Diego, USA, pp. 142-165.

Krishnammoorty, U., Sniffen, C.J., Srern, M.D. \& Van Soest, P.J., 1983. Evaluation of a mathematical model of rumen digestion and an in vitro simulation of rumen proteolysis to estimate the rumen-undegraded nitrogen content of feedstuffs. Brit. J. Nutr. 50, 555-568.

Kung, L. Jr., Maciorowski, K., Powell, K.M., Weidner, S. \& Eley, C.L., 1991. Lupin as a protein supplement for growing lambs. J. Anim. Sci. 69, 3398-3405.

Lanza, M., Pennisi, P. \& Priolo, A., 1999. Faba bean as an alternative protein source in lamb diets: effects on growth and meat quality. Zootec. Nutr. Anim. 25, 71-79.

Lanza, M., Bella, M., Priolo, A. \& Fasone, V., 2003. Peas (Pisumsativum L.) as an alternative protein source in lamb diets: growth performances, and carcass and meat quality. Small Rum. Res. 47, 63-68.

Lanza, M., Fabro, C.,Scerra, M., Bella, M., Pagano, R., Brogna, D.M.R. \& Pennisi, P., 2011. Lamb meat quality and intramuscular fatty acid composition as affected by concentrates including different legume seeds. Ital. J. Anim. Sci. 10:e18, 87-94.

Lestingi, A., Facciolongo, A.M., Caputi Jambrenghi, A., Ragni, M. \& Toteda F., 2016. The use of peas and sweet lupin seeds alone or in association for fattening lambs: Effects on performance, blood parameters and meat quality. Small Rum. Res. 143, 15-23.

Lestingi, A., Facciolongo, A.M., De Marzo, D., Nicastro, F. \& Toteda, F., 2015a. The use of faba bean and sweet lupin seeds in fattening lamb feed. 2. Effects on meat quality and fatty acid composition. Small Rum. Res. 131, 2-5.

Lestingi, A., Toteda, F., Vicenti, A., De Marzo, D. \& Facciolongo, A.M., 2015b. The use of faba bean and sweet lupin seeds alone or in combination for growing lambs. 1. Effects on growth performance, carcass traits, and blood parameters. Pak. J. Zool. 47(4), 989-996.

Macarulla, M.T., Medina, C., De Diego, M.A., Chávarri, M., Zulet, M.A., Martínez, J.A., Nöel-Suberville, C., Higueret, P. \& Portillo, M.P., 2001. Effects of the whole seed and a protein isolate of faba bean (Vicia faba) on the cholesterol metabolism of hypercholesterolaemic rats. Brit. J. Nutr.85, 607-614.

Malekkhahi, M., Tahmasbi, A.M., Naserian, A.A., Mesgaran, M.D., Kleen J.L. \& Parand, A.A., 2015. Effects of essential oils, yeast culture and malate on rumen fermentation, blood metabolites, growth performance and nutrient digestibility of Baluchi lambs fed high-concentrate diets. J. Anim. Physiol. An. N. 99, 221-229.

Masoero, F., Pulimeno, A.M. \& Rossi, F., 2005. Effect of extrusion, expansion and toasting on the nutritional value of peas, faba beans and lupins. Ital. J. Anim. Sci. 4, 177-189.

Milis, Ch. \& Liamadis, D., 2008. Nutrient digestibility and energy value of sheep rations differing in protein level, main protein source and non-forage fibre source. J. Anim. Physiol. An. N. 92 (1),44-52.

Miller, E.L. \& Baig, M.Y., 2002. Critique of a dynamic model of $\mathrm{N}$ metabolism in the lactating dairy cow. J. Anim. Sci. 80 (12), 3369-3371.

Murphy, S.R. \& McNiven, M.A., 1994. Raw and roasted lupin supplementation of grass silage diets for beef steers. Anim. Feed Sci. Technol. 46, 23-35.

Ndiaye, F., Vuong, T., Duarte, J., Aluko, R.E. \& Matar, C., 2012. Anti-oxidant, anti-inflammatory and immunomodulating properties of an enzymatic protein hydrolysate from yellow field pea seeds. Eur. J. Nutr. 51, 29-37.

Offner, A., Bach, A. \& Sauvant, D., 2003. Quantitative review of in situ starch degradation in the rumen. Anim. Feed Sci. Technol. 106, 81-93.

Rodehutscord, M., Young, P. Phillips, N. \& White, C.L., 1999. Wool growth in Merino wethers fed lupins untreated or treated with heat or formaldehyde, with and without a supplementation of rumen protected methionine. Anim. Feed Sci. Tech. 82, 213-226.

Scerra, M., Caparra, P., Foti, F., Cilione, C., Zappia, G., Motta, C. \& Scerra, V., 2011. Intramuscular fatty acid composition of lamb fed diets containing alternative protein sources. Meat Sci. 87, 229-233.

Serrano, X., 1997. The extrusion-cooking process in animal feeding. Nutritional implications. In: P. Morand-Fehr (ed). Feed manufacturing in Southern Europe: New challenges. pp. 107 -114. CIHEAM, (Cahiers Options Méditerranéennes), Zaragoza; n. 26)

Sheridan, R., Hoffman, L.C. \& Ferreira, A.V., 2003. Meat quality of Boer goat kids and Mutton Merino lambs-1. Commercial yields and chemical composition. Anim. Sci. 76, 63-71. 
Sirtori, C.R., Lovati, M.R., Mansoni, C., Castiglioni, S., Duranti, M. \& Magni, C., 2004. Proteins of white lupin seed, a naturally isoflavone-poor legume, reduce cholesterolemia in rats and increase LDL receptor activity in HepG2 cells. J. Nutr. 134, 8-23.

Solanas, E., Castrillo, C., Fondevila, M., Ruiz Narváez, Q.O. \& Guada, J.A., 2008. Effects of cereals and/or protein supplement extrusion on diet utilisation and performance of intensively reared cattle. Livest. Sci. 117, $203-214$.

Stanford, K., McAllister, T.A., Lees, B.M., Xu, Z.J. \& Cheng, K.J., 1996. Comparison of sweet white lupin seed, canola meal and soybean meal as protein supplements for lambs. Can. J. Anim. Sci. 76, 215-219.

Vicenti, A., Toteda, F., Di Turi, L., Cocca, C., Perrucci, M., Melodia, L. \& Ragni, M., 2009. Use of sweet lupin (Lupinusalbus L. var. Multitalia) in feeding for Podolian young bulls and influence on productive performances and meat quality traits. Meat Sci. 82, 247-251.

Viveros, A., Centeno, C., Arija, I. \& Brenes, A., 2007. Cholesterol-lowering effects of dietary lupin (Lupinus Albus var: multolupa) in chicken diets. Poultr. Sci. 86, 2631-2638.

Zagorakis, K., Liamadis, D., Milis, Ch., Dotas, V. \& Dotas, D., 2015. Nutrient digestibility and in situ degradability of alternatives to soybean meal protein sources for sheep. Small Rum. Res. 124, 38-44. 